\title{
Evolution of reef-associated decapod crustaceans through time, with particular reference to the Maastrichtian type area
}

\author{
R.H.B. Fraaije \\ Oertijdmuseum de Groene Poort, Bosscheweg 80, NL-5283 WB Boxtel, the Netherlands
}

Keywords: Decapod crustacean evolution, $\mathrm{K} / \mathrm{T}$ boundary, biostratigraphy

\begin{abstract}
The result of some twenty years of intensive collecting from strata in the Maastrichtian type area is a collection of more than 1,200 generally small-sized anomuran and brachyuran remains. The stratigraphical ranges of the thirty-one species known to date from the Maastricht Formation (Late Maastrichtian) are shown and five successive decapod assemblages are discussed. For the first time, decapod crustacean remains now turn out to be useful biostratigraphic tools on a local to regional scale.
\end{abstract}

\section{Introduction}

Brachyurans utilize a broad array of feeding types, including deposit feeding, filter feeding, seaweed grazing, scavenging and predation. They have been a major component of many marine communities from the Late Jurassic onwards and probably have played an important role in the evolution of marine ecosystems. Unfortunately, they are only rarely described by paleontologists and are also frequently overlooked by biologists in Recent marine communities, especially in the tropics where crabs reach their highest diversity (Zipser \& Vermeij, 1978). Apart from paleoecological factors and possible destruction after death, their apparent scarcity in paleontological collections is probably often due to their relatively small sizes, and therefore the chance of being overlooked in the field (Bishop, 1986; Plotnick et al., 1990). The average size of anomuran and brachyuran crab remains in the finegrained sediments of the Maastrichtian type area is less than $10 \mathrm{~mm}$. Almost all decapod crustacean species from the Maastricht Formation described prior to 1987 by various authors (Bosquet, 1854; van Bĩnkhorst, 1857; Binkhorst van den Binkhorst, 1861; Noetling, 1881; Pelseneer, 1886; Forir, 1887ac, 1889; Mulder, 1981) suffer from a lack of stratigraphic control. A taxonomic revision of most of these species was carried out by Collins et al. (1995). Since 1987, new species from the Maastrichtian type area were described and discussed by Fraaye \& Collins (1987), Feldmann et al. (1990), Jagt et al. (1991, 1993), Collins et al. (1995), Fraaye (1996 a-c, 2002), Fraaye \& van Bakel (1998) and Jagt et al. (2000).

Rigid collecting from six key sections (see Collins et al. 1995, p. 168, fig. 1) during the past two decades has resulted in an extensive, stratigraphically well-documented, decapod, crustacean collection containing over 1,200 specimens and housed at the Oertijdmuseum de.Groene Poort, Boxtel (the Netherlands).

\section{Carapace size and morphology through time}

Crab size is thought to be related to predation pressure (Vermeij, 1978). The relatively small size of the majority of Mesozoic crabs was probably controlled by predation pressure of simultaneously evolving reef teleost fish (Vermeij, 1978) and cooccurring cephalopods. Apart from size selection, predation pressure can also lead to avoidance strategies, i.e., strategies devised to minimize the risks of being predated upon. For crabs, we may envisage four strategies that play a continuous role during their evolution: 1 - to hide and live in crevices; 
2-camouflage thèir carapace; 3 - burrow into loose sediments; 4 - swim in open waters.

Carapace morphology in the first group is generally quadratic or somewhat elongate. Such crabs have been successful from the Late Jurassic onwards and have consistently retained a relatively small size. The vast area of shelf seas with an expansion of redundant bioherms after the Callovian transgression offered various new ecological niches and led to the rapid diversification of prosopids (Förster, 1985). The other three strategies, which probably evolved during the Cretaceous, are characterized by a consîderable size increase through time. The strongly elongate and burrowing Raninidae (frog crabs) are examples of the third group. They appear in the Early Cretaceous and show an increase in size and diversity through time, with maxima during the Late Cretaceous (Feldmann et al., 1996) and Eocene (Förster \& Mundlos, 1982). The Raninidae predominantly lived in shallow-water environments during the Mesozoic but today are, probably due to strong competition during the Cenozoic, mainly deep-water organisms.

The ancestors of the Recent swimming crabs possess carapaces that are wider than long and with antero-lateral spines. They appeared in the latest Cretaceous (Fraaye, 1996a). During the Eocene, the largest swimming crabs quadrupled their carapace size in comparison to their probable Maastrichtian ancestors. It is not mere coincidence that periods of increase in size and diversity of crabs are linked with global sea level high stands (Haq et al., 1987). Major explosive adaptive radiations among crabs occurred during the Late Jurassic, the Albian-Cenomanian, the Campanian-Maastrichtian, and during the Eocene and Miocene transgressions. These periods are characterized by high stands leading to many shallow, more or less isolated, seas. Consequently, more ecospace and new niches for crabs came into existence. In isolated seas, rapid diversification of clades was probably very common. The monophyletic clades produced by this type of event have recently been referred to as 'species flocks' (Yacobucci, 1996). After sea level fall, newly evolved crab populations were forced to retreat and mixing led to strong competition, in turn possibly leading to extinction and faunal turnovers (Fraaye, 1996b). This was followed by periods of stasis, during which a slower and stabilized evolutionary pattern dominated. This model with pulses of rapid diversification, mixing and more stable periods, in roughly $\mathbf{3 0}$ million year cycles, perfectly matches the polyphyletic origin of such groups as the swimming crabs. After each period, however, more and more ecological niches were successfully filled, leading to the recent, most diverse (in size, morphology and feeding strategy) decapod crustacean fauna ever seen on earth.

\section{Cretaceous/Cenozoic decapod crustacean evolution}

The Late Cretaceous diversification of crabs coincides with two similar radiations in other predatory groups, teleost fish and gastropods (Taylor, 1981). These groups also seem to have thrived during periods of transgression with maximum (semi-isolated) shallow-water habitats. The rapid evolution of these predatory groups and others probably had profound effects upon the structure of all benthic communities, and thus also affected crab evolution. To put the evolutionary patterns of decapod crustaceans in the type Maastrichtian in some perspective, faunal data for five other well-studied regions and ages are summarized in Fig. 1. As the majority of the type Maastrichtian decapods is linked with reef-associated carbonates all decapod crustacean faunas compared are from similar environments. Further, all faunas represent the most diverse of their age as presently known. Studies used are Bishop (1983, 1986: Lower Albian, Texas), Müller \& Collins (1991: Upper Eocene, Hungary), Müller (1984: Middle Miocene, Hungary and Austria), Guinot (1985: Recent, French Polynesia) and personal observations (Lower Kimmeridgian, southern Germany).

Brachyuran crab diversity increased in time (Fig. 1), implying a strong evolutionary radiation from the Late Jurassic onwards. It is also clear that certain brachyuran groups played a more prominent role in the shallow marine ecosystems than they do currently. For instance, the Dynomenidae and Raninidae first appeared during the Late Jurassic and Early Cretaceous, respectively. After a rapid evolutionary radiation during the Late Cretaceous, 


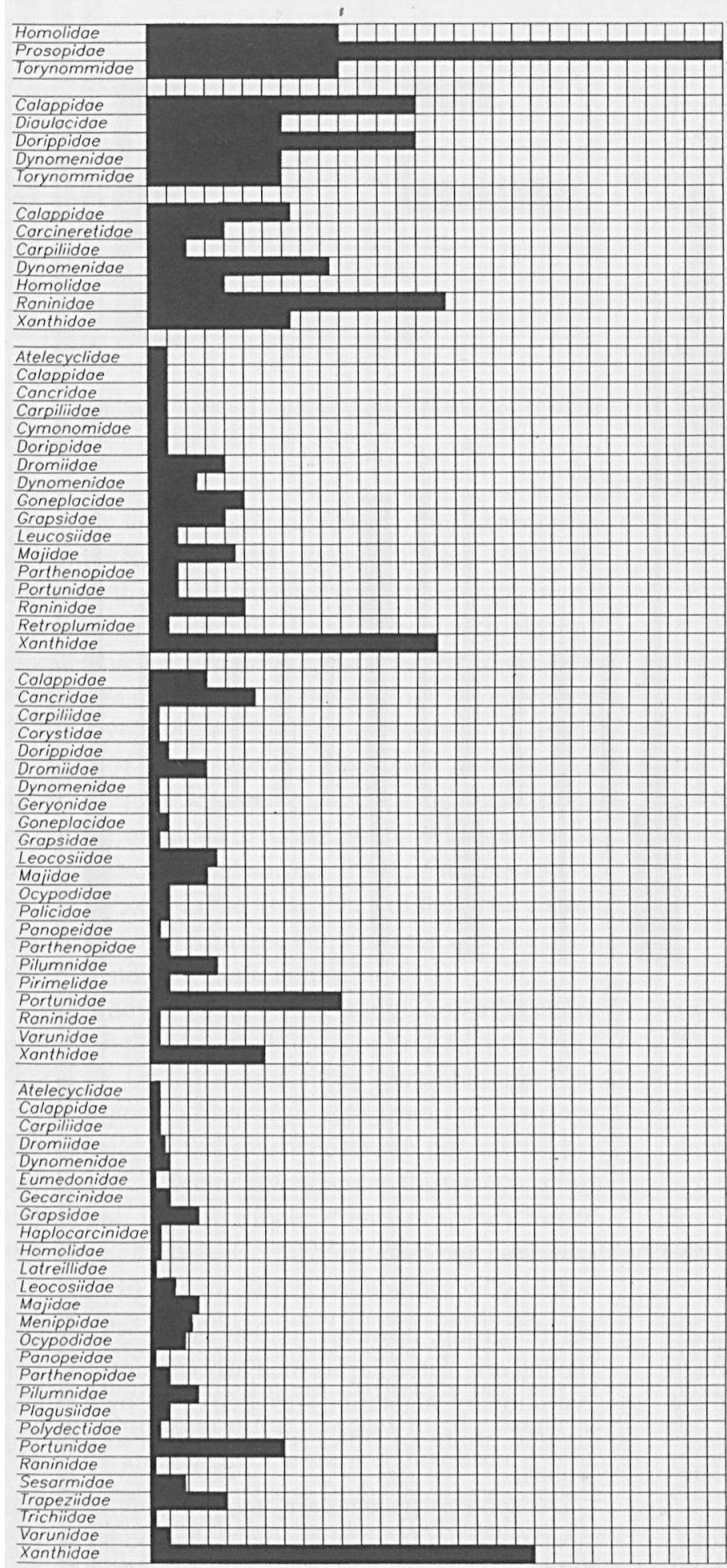

Early Kimmeridgian (155 m.o.), Geisingen, Germany ( 3 families, 5 species)

Early Albian (110 m.a.), Glen Rose, Texas, USA (5 families, 7 species)

Late Moastrichtion (66 m.a.), Maostricht, The Netherlands (7 fomilies, 26 species)

Late Eocene (40 m.a.), Budapest, Hungary (17 families. 66 species)

Middle Miocene (12 m.o.). Budapest. Hungary (22 families, 83 species)

Recent. Pacific

(27 families, 271 species)

Fig. 1. Reef-associated decapod crustacean faunas through time. 


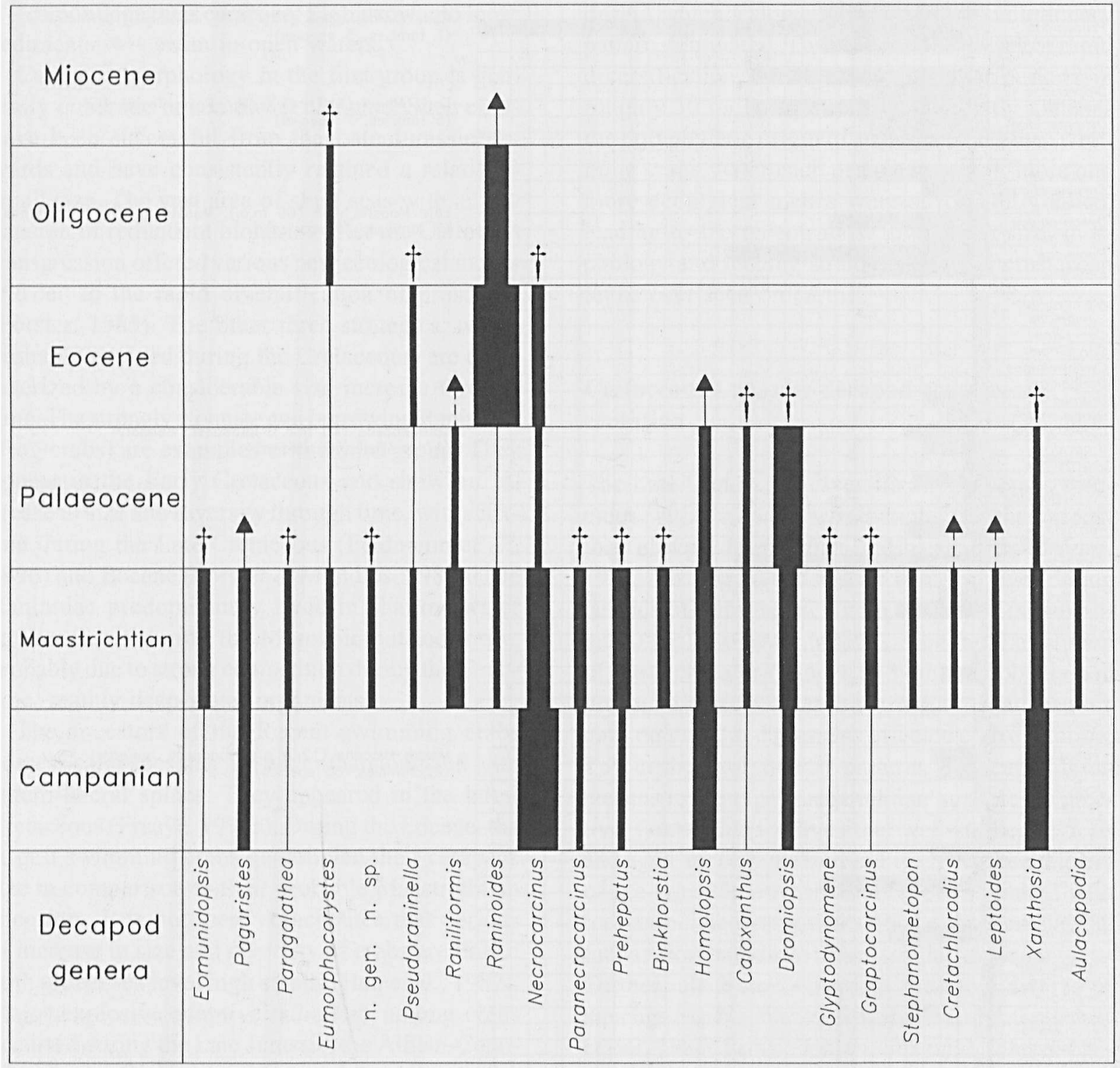

Fig. 2. Stratigraphic ranges of decapod crustacean genera from the Maastrichtian type area.

they dramatically declined from the Eocene onwards. The same may hold true for the Calappidae, although to a somewhat lesser extent. The decline of the Raninidae possibly corresponds to the synchronous biotic radiation of clypeasteroid echinoids and subsequent niche competition and replacement.

Other groups, such as the Portunidae, Cancridae, Majidae, Leucosiidae, Parthenopidae and Grapsidae, however, display a rapid evolutionary radiation in post-Eocene times, as do the Ocypodidae and Pilumnidae from the Miocene onwards. The most suc- cessful group, however, is that of the Xanthidae. Having originated during the Early Cretaceous, their evolutionary adaptations resulted in the by far most diverse group of brachyurans in reef-associated faunas.

Decapod crustaceans are, and probably were, the most important food source for cephalopods (Fraaye \& Jäger, 1996; Jäger \& Fraaye, 1997). The predation pressure on crabs by relatively fast swimming and hunting ammonites such as Placenticeras and Sphenodiscus in the Campanian and Maastrichtian 


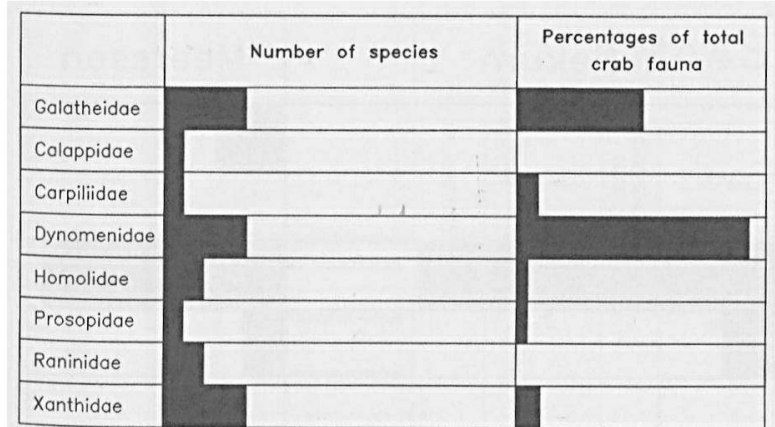

Fig. 3. Number of decapod crustacean species and percentages for the Middle Danian of Fakse (Denmark).

may have led to the introduction of the swimming xanthids (Bishop, 1991; Fraaye, 1996a, 1997). In their turn these well-adapted swimming crabs found a new and abundant food source in planktonic ammonites such as Scaphites spp. (Westermann, 1996). In the Maastrichtian of the Vistula River valley (central Poland) a very high percentage of specimens of Hoploscaphites constrictus have paired, more or less regular punctures in their body chambers, assumed to be the result of decapod crustacean attacks (Radwański, 1996; Fraaye, 1997). Identical holes in the same place of the body chambers are known from the Upper Cretaceous of USA (N.H. Landman, pers. comm.).

The known stratigraphic ranges of all genera present in the Maastrichtian type area are presented in Fig. 2. Of the twenty-three anomuran and brachyuran genera known to date from this area, ten first appear in this interval, ten do not extend beyond the $\mathrm{K} / \mathrm{T}$ boundary, whereas thirteen pass this unscathed, one of which, Paguristes, survives to this day, and two, Cretachlorodius and Leptoides gave rise to Recent forms. Danian decapod crustacean faunas are rather poorly known, partly because of relatively few accessible outcrops (as for instance in the region studied here) and partly because of lack of collection effort. Except, for the fauna of Denmark and Sweden (Collins \& Jakobsen, 1994), and to a lesser degree those from Greenland (Collins \& Rasmussen, 1992), Argentina (Feldmann et al., 1995) and Antarctica (Feldmann et al., 1993), the decapod crustacean data base for the Danian is rather meager, with overall poor biostratigraphic control. Therefore, it is to be expected that of the ten gen- era which apparently do not cross the $\mathrm{K} / \mathrm{T}$ boundary some of them in reality may occur in younger deposits. For two genera, Stephanometopon and Aulacopodia, generic classification and subsequent possible evolutionary offspring is uncertain at the moment. The extinction of Graptocarcinus and possibly Glyptodynomene seems to correspond to a niche-displacement by the apparently better adapted Dromiopsis spp. (Fraaye, 1996b).

Of the fifteen genera known from the Danian of Denmark and Sweden, ten first appear in the Cretaceous (Collins \& Jakobsen, 1994). Percentages of faunal elements in the Middle Danian of Fakse, based upon field observations, are shown in Fig. 3. The successful crossing of the K/T boundary and persistance in Recent faunas of the Calappidae, Carpiliidae and Xanthidae probably are the result of their predatory feeding adaptations, evolved during the Late Cretaceous, especially the specialization of the chelae for breaking and crushing molluscan shells (Taylor, 1981; Zipser \& Vermeij, 1978) and the development of teleplanic larvae. Such a relatively long planktonic larval phase is known in tropical Recent representatives of these families, but is rare or absent in taxa inhabiting cooler seas (Vermeij, 1978).

\section{Substrate and decapod diversity in the Maastrichtian type area}

Percentages for decapod families are plotted and shown separately for the Emael, Nekum and Meerssen members in Fig. 4. From the base of the Emael Member up section, the Paguridae (hermit crabs) show a clear increase in number and diversity, directly correlated with an increased availability of their 'mobile homes', empty gastropod shells. In the Emael Member, the Raninidae and Calappidae dominate. In the Nekum and Meerssen members, the Calappidae remain a more or less constant, important component whereas the Raninidae become proportionally less dominant. The Callianassidae is the commonest group in the Nekum Member, but rapidly decline in the overlying member. Torynommids reached their acme in the Nekum Member and rapidly declined in the lower Meerssen Member, probably as a result of competition with 


\begin{tabular}{|c|c|c|c|}
\hline & Emael & Nekum & Meerssen \\
\hline \multicolumn{4}{|l|}{ Paguroidea } \\
\hline \multicolumn{4}{|c|}{ Galatheidae } \\
\hline \multicolumn{4}{|l|}{ Calappidae } \\
\hline \multicolumn{4}{|c|}{ Carcineretidae } \\
\hline \multicolumn{4}{|l|}{ Carpiliidae } \\
\hline \multicolumn{4}{|c|}{ Dynomenidae } \\
\hline \multicolumn{4}{|l|}{ Homolidae } \\
\hline \multicolumn{4}{|l|}{ Raninidae } \\
\hline Xanthidae & & & \\
\hline
\end{tabular}

Fig. 4. Percentages for decapod crustacean families in the three highest members of the Maastricht Formation in the type area.

the presumably more efficient swimmers amongst the Xanthidae (Fraaye, 1997); some of these latter represent Tethyan invaders (Fraaye, 1996a). The Dynomenidae and Homolidae display the same trend as pagurids going up-section from the Nekum to the Meerssen members. The Galatheidae and Carpiliidae make their first appearance in the Meerssen Member (Fig. 5), but are far outnumbered by other families. Within the interval studied, five successive decapod assemblages may be recognised, as follows (in ascending order):

(I) raninid

(II) raninid/diogenid/calappid

(III) callianassid/calappid/torynommid

(IV) calappid/xanthid/raninid

(V) calappid/dynomenid

The diversity increase between the Emael and Meerssen members is intimately linked with an increase of substrate diversity (Fig. 6). Accumulations of dead shell material grew markedly up section. The entire spectrum of live/dead interactions (ecological consequences of shell accumulation) in benthic communities was referred to as 'taphonomic feedback' by Kidwell \& Jablonski (1983). The change from a predominantly soft-bottom dwelling community in the lower Emael Member (and underlying members), to the firm ground and shell-gravel dwelling communities in the Nekum and Meerssen members, was probably triggered by the mass oc- currence of seagrass fields during deposition of the uppermost Emael, Nekum and lower Meerssen members (Liebau, 1978; Felder et al., 1980; Voigt, 1981). The sea grasses enabled the colonisation of small epizoans such as bryozoans (Voigt, 1981), foraminifera (Sprechmann, 1981) and calcareous algae (Brasier, 1975). Sediments which accumulate around sea grass communities are distinctive and, if they escape channeling and other forms of associated erosion within the biotope, they stand a high chance of preservation (Brasier, 1975). Sea grass is notable for its ability to influence the character of the sediment substrate. The dense plant growth probably reduced current velocities, whereas the rhizomes stabilised the accumulated sediments. Infaunal filter feeders, e.g., Protocallianassa faujasi, thrived in the nutrient-enriched sediments around sea grasses, making use of things such as decaying plant material (Sven et al., 2001). The accumulated dead hard parts of the sea grass-epibionts facilitated the colonization of other epizoans such as fungi, sponges, corals, brachiopods, serpulids, lunulitiform bryozoans, boring and encrusting bivalves, sessile gastropods and cirripedes. In the lower Meerssen Member (units IVf-1 to -4) this colonization finally led to the development of small-sized bioherms, vertically and laterally alternating with hard grounds (Voigt, 1974; van den Elsen, 1985) and relief infillings (Zijlstra, 1995). Cavities in hardgrounds 


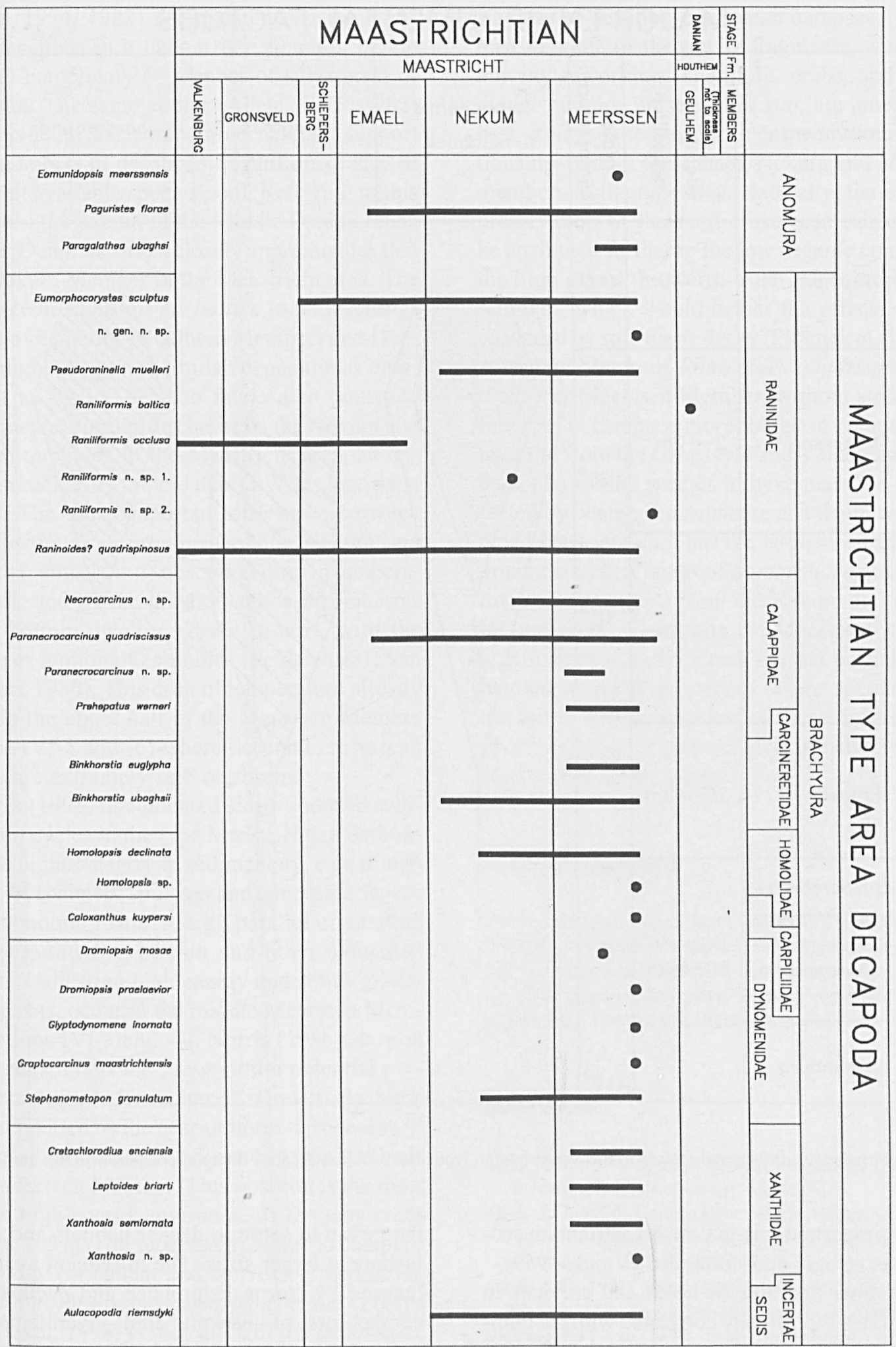

Fig. 5. Decapod crustacean species range chart in the Maastrichtian type area. 
MAJOR ENVIRONMENTAL FACTORS

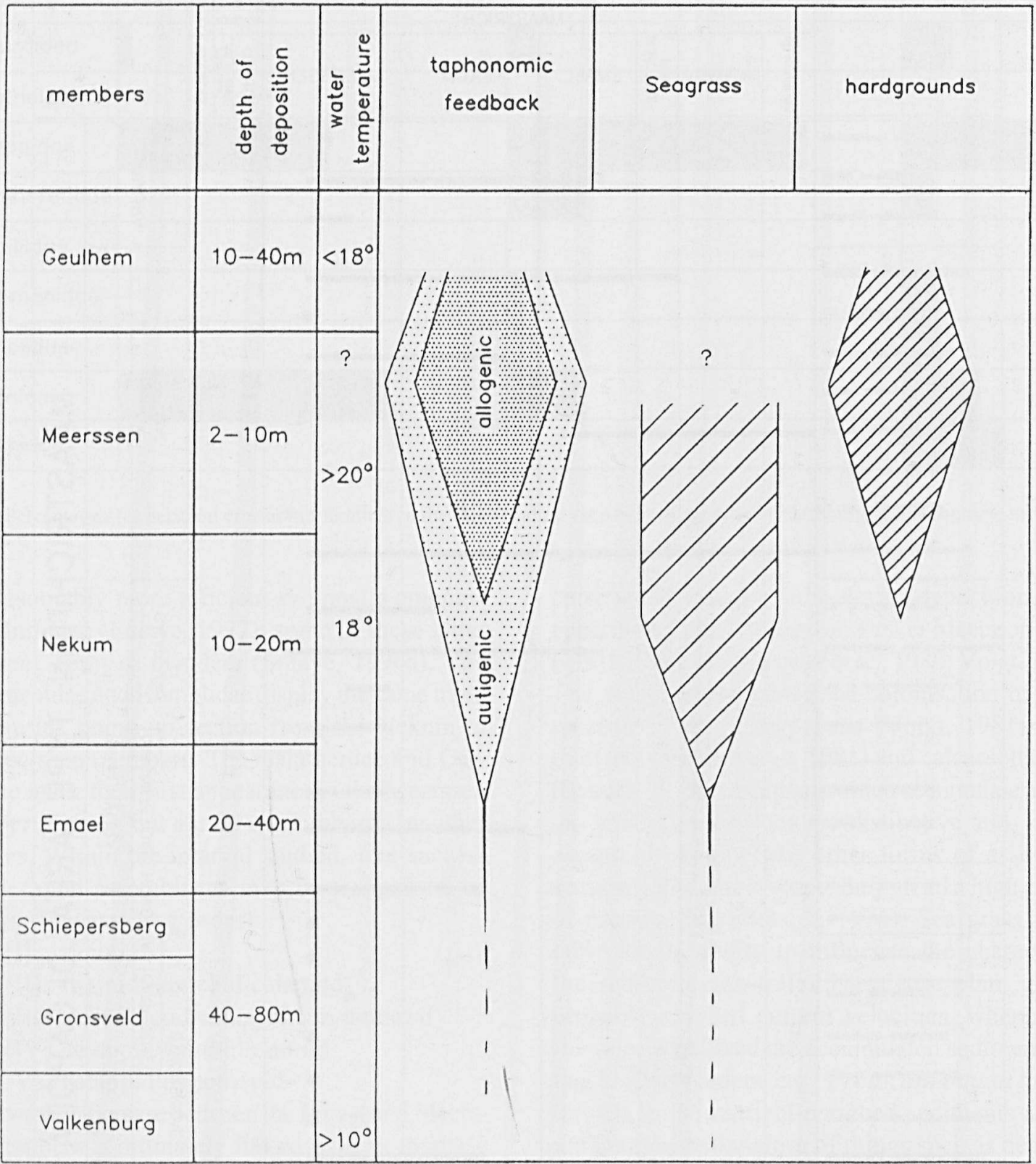

Fig. 6. Major palaeoenvironmental factors in the Maastrichtian type area which influenced decapod crustacean communities.

played an important role in Late Maastrichtian ecosystems as refugia and domiciles (Voigt, 1959).

The number and size of holes and crevices in reef substrates is positively correlated with the number and size of decapod crabs and shrimps (ReakaKudla, 1990). These decapod crustaceans each prey on their own and each others' juveniles, forcing the larvae to settle in deeper habitats and migrate inshore at larger sizes. The infrequent availability (caused by storm disturbance and occupation by competitors) of holes and adult-juvenile predatory interactions was probably important in the evolution of decapod crustaceans in reef communities over time. 
Abele $(1974,1982)$ documented that the number of decapods in a habitat is a function of the structural complexity (= number of substrates) of that habitat The same author (Abele, 1976, 1982) also concluded that comparable habitats support similar numbers of decapods, regardless of size of the overall available species pool. Referring to this hypothesis, the habitat of the Middle Danian fauna of Fakse (Denmark) most closely approximates that of the Nekum Member in the Maastricht area. The occurrence of Raniliformis baltica in both settings (Danian of Limburg [Geulhem Member] and Denmark) might suggest a similar depositional environment as well. The crab fauna also points to environmental similarities between the Nekum and Geulhem members in the Maastricht area, an observation backed by crinoid data (J.W.M. Jagt, pers. comm.). The most important difference between the depositional environment of the Nekum and Geulhem members is a substantial drop in temperature, indicated by the drastic decline of bioherms and all bottom-dwelling fossil groups, with the possible exception of echinoids (Felder, 1981; van den Elsen, 1986). This drop of temperature already started in the upper half of the Meerssen Member (sections IVf-5 and -6) where decapod crustacean remains are extremely rare or absent.

Zijlstra (1995) documented storm-induced sedimentation cycles in the type Maastrichtian carbonates. The highest degree of sedimentary, e.g., trough cross beds, channels, spillover and tempestite sheets, and taphonomic features, e.g., parallel orientation of the serpulid Pyrgolopon and other elongated bioclasts, indicating high energy and storm-generated deposits, occur in the middle Meerssen Member (sections IVf-3 and -4). Norris (1986) showed that amongst crabs the preservation potential produced by storm-induced burial is relatively high. This is supported by the near-uniform "upside-down" position of carapaces in the storm-generated beds of the Meerssen Member. This position is the most stable in high-energy environments in many crabs (Schäfer, 1951). The successive change in carapace morphology (ornament and convexity) within the genera Raniliformis and Eumorphocorystes (Fraaye \& van Bakel, 1998) is indicative of the persistence of such a depositional environment over an evolutionarily significant period of time. The extreme fragility of decapod crustacean carapaces, in contrast to some of their claw fragments, would rule out any reworking. Therefore, crabs, and in particular raninids preserved in situ, are amongst the best groups suited to document evolutionary relationships within the Emael, Nekum and Meerssen members in the type area. Naturally, the excellent preservation of decapod crustacean remains may be attributed further to the low organic content and the high $\mathrm{pH}$ of the warm-water depositional environment, which would buffer the effects of acids produced by soft-tissue decay (Plotnick et al., 1988). A second bloom of Raninoides quadrispinosus in the lower Meerssen Member, without striking differences in carapace morphology in comparison to material from the Gronsveld and Valkenburg members, shows this species to have been the least affected by changes in substrate and depth within the type Maastrichtian. Thus far, large-sized and highly ornamented specimens of Eumorphocorystes sculptus are only known from the Nekum and underlying members, whereas in the Meerssen Member a significantly smaller sized and but partially ornamented morphotype occurs. More specimens are needed to determine whether these different morphotypes are ontogenetic or phylogenetic (van Bakel et al., work under way).

\section{Acknowledgements}

I wish to thank to J.W.M. Jagt (Maastricht), G. van der Zwaan (Utrecht), F. Schram (Amsterdam) and J. Meulenkamp (Utrecht) for their suggestions leading to improvement of this paper. $T$. van Hinte prepared the figures. This is a contribution to IGCP project 362, "Tethyan and Boreal Cretaceous".

\section{References}

Abele LG. 1974. Species diversity of decapod crustaceans in marine habitats. Ecology 55: 156-161.

Abele LG. 1976. Comparative species richness in fluctuating and constant environments: coral-associated decapod crus-taceans. Science 192: 461-463.

Abele LG. 1982. Bíogeography. In: Bliss DE (ed.). The Biology of Crustacea: 241-304. New York: Academic Press.

Binkhorst JT van. 1857. Neue Krebse aus der Maestrichter Tuffkreide. Verh. naturhist. Ver. Preuss. Rheinl. Westf. 14: $107-110$. 
Binkhorst van den Binkhorst JT. 1861. Monographie des Gastéropodes et des Céphalopodes de la craie supérieure du Limbourg, suivie d'une description de quelques espèces de Crustacés du mềme dépôt crétacé, avec dix-huit planches desinées et lithographiées par C. Hohe, de Bonn. Bruxelles/ Maastricht : C. Muquardt/Muller Frères.

Bishop GA. 1983. Fossil decapod crustaceans from the Lower Cretaceous, Glen Rose Limestone of Central Texas. Trans. San Diego Soc. Nat. Hist. 20: 27-55.

Bishop GA. 1986. Occurrence, preservation, and bìogeography of the Cretaceous crabs of North America. In: Gore RH, Heck KL (eds). Crustacean biogeography: 111-142. Rotter-dam: Balkema.

Bishop GA. 1991. Xanthosia occidentalis Bishop, 1985, and Xanthosia spinosa, new species, two late Cretaceous crabs from the Pierre Shale of the Western Interior. $J$. crust. Biol. 11: 305-314.

Bosquet J. 1854. Les Crustacés fossiles du Terrain Crétacé du Limbourg. Inx Verhandelingen uitgegeven door de commissie belast met het vervaardigen eener geologische beschrijving en kaart van Nederland, Tweede deel: 1-27 [10-137]. Haarlem: A.C. Kruseman.

Brasier MD. 1975. An outline history of seagrass communities. Palaeontology 18: 681-702.

Collins JSH, Fraaye RHB, Jagt JWM. 1995. Late Cretaceous anomurans and brachyurans from the Maastrichtian type area. Acta palaeont. pol. 40: 165-210.

Collins JSH, Jakobsen SL. 1994. A synopsis of the biostratigraphic distribution of the crab genera (Crustacea, Decapoda) of the Danian (Palaeocene) of Denmark and Sweden. Bull. Mizunami Fossil Mus. 21: 35-46.

Collins JSH, Rasmussen HW. 1992. Upper Cretaceous-Lower Tertiary decapod crustaceans from West Greenland. Groenl. geol. Unders. Bull. 162: 1-46.

Elsen JMII van den. 1985. Een mesofossiel-analyse van de kalkstenen in de groeve Blom. Natuurhist. Maandbl. 74: 116-118.

Felder PJ. 1981. Mesofossielen in de kalkafzettingen uit het Krijt van Limburg. Naturhist. Maandbl. 70: 201235.

Felder PJ, Felder WM, Bromley RG. 1980. The type area of the Maastrichtian Stage. The Upper Cretaceous and Danian of NW Europe. 26th Int. Geol. Congr: 118-162.

Felder WM. 1975. Lithostratigrafie van het Boven-Krij̀t en het Dano-Montien in Zuíd-Limburg en het aangrenzende gebied. In: Zagwijn WH, Staalduinen CJ van (eds). Toelichting bij geologische overzichtskaarten van Nederland: 63-72. Haarlem: Rijks Geologische Dienst.

Feldmann RM, Jagt JWM, Tshudy DM. 1990. Late Maastrichtian isopod and decapod Crustacea from Haccourt, northeastern Belgium. Meded. Rijks Geol. Dienst 44: 2335 .

Feldmann RM, Tshudy DM, Thomson MRA. 1993. Late Cretaceous and Paleocene decapod crustaceans from James Ross Basin, Antarctica Peninsula. Mem. Paleont. Soc. 28: $1-41$.
Feldmann RM, Casadio S, Chirino-Galvez L, AguirreUrreta M. 1995. Fossil decapod crustaceans from the Jaguel and Roca formations (Maastrichtian-Danian) of the Neuquén Basin, Argentina. Mem. Paleont. Soc. 43: 1-22.

Feldmann RM, Vega F, Tucker AB, Garcia-Barrera $P$, Avendano J. 1996. The oldest record of Lophoranina (Decapoda: Raninidae) from the Late Cretaceous of Chiapas, southeastern Mexico.Jour. Paleo, 70: 296-303.

Forir H. 1887a. Contributions à l'étude du système crétacé de la Belgíque. I. Sur quelques poissons et crustacés nouveaux ou peu connus. Ann. Soc. géol. Belg. 14: 2556.

Forir H. 1887b. Contributions à l'étude du système crétacé de la Belgique. II. Études complémentaires sur les crustacés. Ann. Soc. géol. Belg. 14: 155-175.

Forir H. 1887c. Contributions à l'étude du système crêtacế de la Belgique. III. Bibliographie et tableau des thoracostracếs décrits jusqu”à ce jour. Ann. Soc. géol. Belg. 14: 176-195.

Forir H. 1889. Contributions à l'étude du système crêtacế de la Belgique. IV. Troisième note sur des poíssons et crustacés nouveaux ou peu connus. Ann. Soc. géol. Belg. 16: 445-460.

Förster R. 1985. Evolutionary trends and ecology of Mesozoic decapod crustaceans. Trans. Roy. Soc. Edinb. 76: 299-304.

Förster R, Mundlos R. 1982. Krebse aus dem Alttertiär von Helmstedt und Handorf (Niedersachsen). Palaeontogr. A179: 148-184.

Fraaye RHB. 1996a. Cretachlorodius enciensis, a new Tethyan immigrant from the type Maastrichtian. Jour. Paleo 70: 293-296.

Fraaye RHB. 1996b. Graptocarcinus maastrichtensis and Caloxanthus kuypersi from the type Maastrichtian. Jour. Paleo 70: 463-465.

Fraaye RHB. 1996c. Late Cretaceous swimming crabs: radiation, migration, competition, and extínction. Acta Geol. Pol. 46: 269-278.

Fraaye RHB. 2002. New calappid crabs (Crustacea, Decapoda, Brachyura) from the Late Maastrichtian of the Netherlands. Jour. Paleo 76: 913-917.

Fraaye RHB, Bakel BWM van. 1998. New raniníd crabs (Crustacea, Decapoda, Brachyura) from the late Maastrichtian of the Netherlands. Geol. Mijnbouw 76: 293299.

Fraaye RHB, Collins JSH. 1987. Prehepatus werneri from the type Maastrichtian of The Netherlands. Jour. Paleo 61: $549-551$.

Fraaye RHB, Jäger M. 1995. Decapods in ammonite shells: examples of inquilinism from thew Jurassic of England and Germany. Palaeontology 38: 63-75.

Goeke GD. 1985. Decapod Crustacea: Raninidae. Mém. Mus. natn Hist. nat. Paris A133: 205-228.

Guinot D. 1985. Crustacea. In: Ríchard G (ed.). A first compendium of French Polynesian sea-dwellers: 446-455. Tahiti: Fifth International Coral Reef Congress.

Haq BU, Hardenbol J, Vail PR. 1987. Chronology of fluc- 
tuating sea-levels since the Triassic. Science 235: 11561167.

Jäger M, Fraaye RHB, 1997. The diet of the Early Toarcian ammonite Harpoceras falciferum.: Palaeontology 40: 557574.

Jagt JWM, Collins JSH, Fraaye RHB. 1991 A new late Maastrichtian xanthid crab from southern Limburg (The Netherlands). Cret. Res. 12: 553-560.

Jagt JWM, Collins JSH, Fraaye RHB. 1993, A new early Palaeocene genus of raninid crab (Crustacea, Decapoda) from Denmark, southern Sweden and The Netherlands. Contr. Tert. Quatern. Geol. 30:177-182.

Jagt JWM, Fraaye RHB, Bakel BWM van. 2000. Late Cretaceous decapod crustacean faunas of northeast Belgium and the southeast Netherlands. Studi e Ricerche, Assoc. Amici Mus. civ. 'G. Zannato', 37-42.

Kidwell SM, Jablonski D. 1983. Taphonomic feedback: ecological consequences of shell accumulation. In; Tevesz MJS, McCall PL (eds). Biotic interactions in Recent and fossil benthic communities: 195-248. New York: Plenum Press.

Kidwell SM, Aigner T. 1985. Sedimentary dynamics of complex shell beds: implications for ecologic and evolutionary patterns. In: Bayer U, Seilacher A (eds). Sedimentary and evolutionary cycles: 382-395. Berlin: Sprìnger.

Liebau A. 1978. Palâobathymetrische und palâoklìmatische Veränderungen im Mîkrofaunenbild der Maastrichter Tuffkreide. N. Jb. Geol. Paläont. Abh. 157: 119-122.

Mulder EWA. 1981. Bijdrage tot de karakterisering van de kreeft Callianassa faujasi Desmarest. Natuurhist. Maandbl. 70: 170-174.

Müller P. 1984. Decapod Crustacea of the Badenian. Geol. Hung., Ser.Palaeont. 42: 1-317.

Müller P, Collins JSH. 1991. Late Eocene coral-associated decapods (Crustacea) from Hungary . Contr. Tert. Quatern. Geol. 28: 47-92.

Noetling F. 1881. Ueber einige Brachyuren aus dem Senon von Mastricht und dem Tertiâr Norddeutschlands. $Z$. dt. geol. Ges. 33: 357-371.

Norris RD. 1986. Taphonomic gradients in shelf fossil assemblages: Pliocene Purisimia Formation, California. $\mathrm{Pa}$ laios 3: 256-270.

Pelseneer P. 1886. Notice sur les crustacés décapodes du Maestrichtien du Limbourg, Bull. Mus. r. Hist. Nat. Belg. 4. 161-175.

Plotnick RE, Baumiller S, Whetmore KL. 1988. Fossilization potential of the mud crab, Panopeus (Brachyura: Xanthidae) and temporal variability in crustacean taphonomy. Palaeogeogr., Palaeoclimatol., Palaeoecol. 63: 27 43.

Plotnick RE, McCaroll S, Powell E. 1990. Crab death assemblages from Laguna Madre and vicinity, Texas. Palaios 5: 81-87.

Radwański A. 1996. The predation upon, and the extinction of, the latest Maastrichtian populations of the ammonite species Hoploscaphites constrictus (J. Sowerby, 1817) from the Middle Vistula Valley, Central Poland, Acta Geol. Pol. 46: 117-135.
Rathbun MJ. 1937. The oxystomatous and allied crabs of America. U.S. Natl Mus. Bull. 166: 1-272.

Reaka-Kudla ML. 1990. Processes regulating biodiversity in coral reef communities on ecological vs. evolutionary time scales. Crit. Iss. Biodiv. Symp.: 61-70.

Savazzi E. 1981. Functional morphology of the cuticular terraces in Ranina (Lophoranina) (brachyuran decapods; Eocene of NE Italy). $N \times J b$. Geol. Paläont. Abh. 162; 231-243.

Savazzi E. 1982. Burrowing habits and cuticular sculptures in Recent sand-dwelling brachyuran decapods from the Northern Adriatic Sea (Mediterranean). N.Jb. Geol. Paläont. Abh. 163: 369-388.

Savazzi E. 1994. Functional morphology of boring and burrowing invertebrates. In: Donovan SK (ed.). The palaeobiology of trace fossils: 43-83. Chichester: Wiley \& Sons.

Savazzi E, Huazhang P. 1994. Experiments on the frictional properties of terrace sculptures. Lethaia 27: 325 336.

Schäfer W. 1951. Fossilisations-Bedingungen brachyurer Krebse, Abh. Senckenb, naturf, Ges, 485: 221-238.

Seilacher A. 1961. Krebse ìm Brandungssand. Natur u. Volk 91: 257-264.

Serène R, Umali AF. 1972. The family Raninidae and other new and rare species of brachyuran decapods from Philippines and adjacent regions. Philippine Jour. Sci. 99: 21-105.

Sprechmann P. 1981. Paleocommunities and paleobathymetry of Maastrichtian sublittoral benthonic foraminifera from western Europe. $N$. Jb. Geol. Paläont. Abh. 162; 188230.

Sven C, Fraaije RHB, Zwaan GJ van der. 2001. Polymorphy and extinction of the Late Cretaceous burrowing shrimp Protocallianassa faujasi and first record of the genera Corallianassa and Calliax (Crustacea, Decapoda, Thalassinoidea) from the Cretaceous. Contr. Zool. 70: 8598.

Taylor JD. 1981. The evolution of predators in the late Cretaceous and their ecological significance. In: Forey PL (ed.). The evolving biosphere: 229-240. Cambridge: Cambridge University Press.

Vermeij GJ. 1978. Blogeography and adaptation - Patterns of marine life. Cambridge: Harvard University Press.

Voigt E. 1959. Die ökologische Bedeutung der Hartgrunde ("Hardgrounds") in der oberen Kreide. Paläont. Z. 33: 129-147.

Voigt E. 1974. Über die Bedeutung der Hartgrunde (Hardgrounds) für die Evertebratenfauna der Maastrichter Tuffkreide. Natuurhist. Maandb. 63: 32-39.

Voigt E. 1981. Upper Cretaceous bryozoan-seagrass association in the Maastrichtian of The Netherlands. In: Larwood GP, Nielsen C. (eds). Recent and fossil Bryozoa: 281298. Fredensborg: Olsen \& Olsen.

Westermann GEG. 1996. Ammonite life and habitat. In: Landman N, Tanabe $\mathrm{K}$ \& Davis RA. (eds). Ammonoild paleobiology: 607-707. New York: Plenum Press.

Yacobucel MM. 1996. Plasticity of developmental timing as the underlying cause of high speciation rates in am- 
monoids: an example from the Cenomanian Western Interior Seaway of North America. 1th Int. Symp. Cephalopods - Present and Past: 166-167.

Zijlstra JJP. 1995. Sedimentology of the Late Cretaceous and Early Tertiary (Tuffaceous) Chalk of Northwest Europe. Geol. Ultraiectina 119: 1-192.
Zipser E, Vermeij GJ. 1978. Crushing behavioor of tropical and temperate crabs. J. Exp. Mar. Biol. 31: 155-172.

Received: 15 March 2003 